\title{
RECOGNIZING THE RIGHT OF THE THIRD GENDER TO MARRIAGE AND INHERITANCE UNDER HINDU PERSONAL LAW IN INDIA
}

\author{
DIPAYAN CHOWDHURY, \\ Symbiosis Law School (Pune, India) \\ ATMAJA TRIPATHY, \\ Symbiosis Law School (Pune, India)
}

DOI: 10.21684/2412-2343-2016-3-3-43-60

One of the most implicit foundations of a person's identity today, in a cultural, national as well as global context, is the collegial relationship which he or she shares with another person, that relationship ultimately giving formation to a conjoint, consolidated and co-dependent recognition of the two as one under the law, particularly with respect to resolving socio-familial issues such as those of parentship, guardianship, adoption, succession and inheritance, among others.

The term "relationship" mentioned above is connotative of marriage and the following paper attempts to look at this relationship, in its connection to the various facets of one's personal identity as a citizen, from the perspective of a third gender Hindu Indian national. Though the right to marry of such an individual, especially as seen against the backdrop of the existing communal ethos in the country, may be accepted as being some form of a heterodoxy, it still falls short of qualifying as anything that could be called, in the least, "heretical" or even illegal.

While due to the constraints of time the authors of the present study have been compelled to restrict the same to only a particular division of nationality and a further specific sub-class thereof, the authors sincerely hope that this study will inspire further such examinations into its chosen subject within the field domains of other religions and nationalities.

Keywords: third gender; right to marry; Hindu personal law. 
Recommended citation: Dipayan Chowdhury \& Atmaja Tripathy, Recognizing the Right of the Third Gender to Marriage and Inheritance under Hindu Personal Law in India, 3(3) BRICS Law Journal 43-60 (2016).

\section{Table of Contents}

\section{Introduction}

2. Marriage under Hindu Customary Law 2.1. Queer Marriages in the Hindu Context

3. Recognition of Third Gender in India

4. Legal Status of Marriage and Its Consequences under Hindu Law

5. The Case for an Inclusive Interpretation of Marriage

\subsection{An Implication of Non-Recognition of Third Gender Rights under Personal Laws \\ 5.2. Recognizing Hijra Gharana's Right of Inheritance \\ 6. Conclusion}

\section{Introduction}

Marriage is believed to be one of the most essential constituents of a person's identity, both in a socio-economic and in a politico-legal sense. The institution of marriage, which is a codified and legally identifiable relationship between two people, has immense public significance, as it garners much footing in respect of the rights and obligations, especially those of property, succession, inheritance and such related rights, which eventually stem from the solemnization of a marriage. 'Today, marriage is not only a recognized civil right ${ }^{2}$ that belongs to each and every member or citizen of the state, but also a concept that has both national and international acceptance. ${ }^{3}$ It is on this account that it can be said that the enforcement of marriage as an individual's right is imperative on the state, particularly in regard to all such laws and policies that emanate from it and, further, regulate the interpersonal domain of marriage.

Indra Sarma v. V.K.V. Sarma, 2013 (14) SCALE 448 ("Marriage as an institution has great legal significance and various obligations and duties flow out of marital relationship, as per law, in the matter of inheritance of property, successionship, etc."); see also Perez v. Lippold, 198 P.2d 17, 20.1 (1948); Loving v. Virginia, 388 U.S. 1 (1967).

2 Skinner v. Oklahoma, 316 U.S. 535 (1942).

3 International Covenant on Civil and Political Rights, December 19, 1966, 999 U.N.T.S. 171 (1976), Art. 23; Universal Declaration of Human Rights, December 10, 1948, G.A. res. 217A (III), U.N. Doc A/810 at 71 (1948), Art. 16; International Covenant on Economic, Social and Cultural Rights, December 16, 1966, 993 UNTS 3 / [1976] ATS 5 / 6 ILM 360 (1967), Art. 10; European Convention on Human Rights, November 4, 1950, 213 U.N.T.S. 221, Art. 12. 
The right to marry, now a constitutional right in India, permits persons to make the choice of spouse according to their own free will, and this right cannot be infringed by the state. ${ }^{4}$ In the Indian context, the right of life and personal liberty under Article 21 of the Constitution does not merely provide for a physical existence, rather it implies the existence of human life which is qualitative and meaningful. ${ }^{5}$ The recognition of inherent human dignity is a prerequisite for the warranting of rights under Article $21 .{ }^{6}$ The right to marry being crucial for retaining individual dignity and for enjoying a meaningful human existence, Indian courts have therefore interpreted marriage to be an essential right under Article 21 of the Constitution.?

When marriage is such an essential civil right that is fundamental to each and every citizen of the country, is it justifiable to ostracize people merely on the grounds of their non- conformity to a stereotyped differentiation of binary genders? Sadly, even though the right to marry as per one's own choice has been recognized as a fundamental right, the contemporary social scenario which third gender people are facing strips them of this basic right. The personal law recognizing Hindu marriage and law enforcement agencies make no effort to guarantee third gender people their fundamental right to marry any individual of their own choice.

\section{Marriage under Hindu Customary Law}

Under Hindu law, marriage has a divine origin and is essentially understood to mean a sacred union of two individuals for the performance of religious duties. ${ }^{8}$ Marriage, as per Vedic scriptures, is known to exist in eight different forms, namely, brahma, asura, daiva, arsha, prajapatya, paisaca, rakshasa and, lastly, gandharva. ${ }^{9}$ Amongst these, Gandharva vivaha is the most pious and widely used form of marriage in view of the fact that it is marriage based on mutual love and attraction between two individuals. This type of marriage supports the performance of third gender weddings as the only qualification it demands prior to solemnization is mutual love and attraction ${ }^{10}$ between the marrying individuals, accompanied by the performance

4 Loving, 388 U.S.

5 Olga Tellis and Ors. v. Bombay Municipal Corporation and Ors., (1985) 3 SCC 545.

6 Maneka Gandhi v. Union of India, AIR 1978 SC 597; Francis Coralie v. Union Territory of Delhi, (1981) 1 SCC 608.

7 Mr. X v. Hospital Z, AIR 1999 SC 495.

8 Swarajya Lakshmi v. G.G. Padma Rao, AIR 1974 SC 165.

9 Rajbali Pandey, Hindu Samakaras: Socio-Religious Study of the Hindu Sacraments (2 ${ }^{\text {nd }}$ ed., Delhi: Motilal Banarasidass Publishers, 1969).

10 Sir Dinshaw Fardunji Mulla, Mulla Hindu Law 605 (12 ${ }^{\text {th }}$ ed., LexisNexis, 1960). 
of relevant ceremonies and customs." Common customary Hindu rituals include the exchange of garlands and an invocation before the sacred fire known as saptapadi. These ceremonies form an important aspect even in the legislation codifying Hindu marriage wherein the absence of the customary ceremonies will have the effect of not solemnizing the marriage in its true sense. ${ }^{12}$ Gandharva marriage is primarily performed with mutual consent between individuals partaking in the marriage and, as such, requires no witnesses, no ceremonial official and no parental consent. Despite its disputed status as a suitable form of marriage in Hindu sacred texts, the $4^{\text {th }}$-century literary masterpiece Kamasutra accepts Gandharva vivaha as the best form of marriage because it is based on mutual attraction or anuraga. ${ }^{13}$

In the Hindu narrative, one's choices, known as samskaras, are the cumulative outcome of the desires and wants of an individual's past lives, a pattern representing one's conditioned as well as innate tendencies. ${ }^{14}$ The word samskara is also understood to mean a rite of passage, that is, a rite by exercise of which one attains to almost near completion or self-fulfilment. ${ }^{15}$ Hinduism believes life's objective to be four-fold, and the four tenets that form the basis of this belief are artha, kama, dharma and moksha. ${ }^{16}$ Hindus believe in the rebirth of human life so as to be able to work through the unfulfilled attachments of previous births and, thus, ultimately move towards liberation from the attachments along with freedom from the cycle of birth and death. ${ }^{17}$ This urge to work through one's attachments constitutes one's individual and eternal dharma, and it is considered inborn, innate and inerasable. It is in this context that it can be said, since marriage is an essential requisite for the fulfilment of one's individual dharma, that a person possessing an innate desire to love another person may do so without considering the gender of that person. Individuals, irrespective of their sex or gender, should have the right to express such desire in the form of marriage if they wish to do so, and, if this union with the person

11 See, e.g., Bhaurao Shankar Lokhande \& Anr v. State of Maharashtra \& Anr., AIR 1965 SC 1564 ("The two ceremonies essential to the validity of a Hindu marriage, i.e. invocation before the sacred fire and sapatapadi, are also a requisite part of a'Gandharva' marriage, unless it is shown that some modification of these ceremonies has been introduced by custom in any particular community or caste.").

12 S. 7, Hindu Marriage Act, Act No. 25 of 1955; see also Bhaurao, AIR 1965 ("Unless the marriage is celebrated or performed with proper ceremonies and due form, it cannot be said to have been 'solemnised' within the meaning of S. 17.").

13 Ruth Vanita, Love's Rite: Same-Sex Marriage in India and the West (New York: Palgrave Macmillan, 2005; New Delhi: Penguin Books, 2005).

14 Dieter Senghass, The Clash within Civilisations: Coming to Terms with Cultural Conflicts (London: Routledge, 2005).

15 U.R. Ananthamurthy, Samskara: A Rite for a Dead Man (Oxford: Oxford University Press, 2012).

16 R.C. Mishra, Moksha and the Hindu Worldview, 25(1) Psychology \& Developing Societies 21 (2013).

17 Nevill Druru, Reincarnation: Exploring the Concept of Reincarnation in Religion, Philosophy and Traditional Cultures 6 (New York: Barnes \& Nobles Books, 2002). 
of their choice is not allowed, it would constitute a potential intrusion into the way of their attainment of moksha or eternal liberation.

\subsection{Queer Marriages in the Hindu Context}

Against the historical backdrop, Hindu marriages have never been performed in a uniform manner but have always been in accordance with the customs of different schools that individuals preferred to follow. ${ }^{18}$ In the earlier Vedic society, third gender people were bestowed with all the liberties and basic rights, including that of marriage, which were guaranteed to any other individual. ${ }^{19}$ Later, third-sex citizens' existence and marriage were also recognized in the Kamasutra. ${ }^{20}$ In fact, Hindu jurisprudence has not explicitly prohibited queer marriages, such forms of non-binary gender marriages are laid down in most of the major Hindu texts that are followed ${ }^{21}$ as has also been enumerated over the years by a number of personalities of religious position, priestly scholars and spiritual teachers who have espoused their respective opinions on the same, deriving their knowledge from their own readings, experience or practice. ${ }^{22}$ These opinions have been simultaneously recorded in the form of different treatises which exist today for our study. ${ }^{23}$

One of the most prominent examples of queer marriage in Hindu literature is the story of Princess Sikhandini that was written into the epic Mahabharata. Princess Sikhandini married a woman she was in love with, and subsequently she was transformed into the physical sex of a man. Despite not having married again the woman she loved but this time as a man, the marriage remained a valid marriage. ${ }^{24}$ The story of Mohini and Aravan also proves the existence of non-binary gender marriages in the ancient historical past. Arjuna's son Aravan's only wish before his sacrificial death was to be married for the last night of his life. In order to satisfy this last desire, Lord Krishna himself transformed into the female form of Mohini and married Aravan. ${ }^{25}$ The marriage was considered to be valid as per customary Hindu laws. These stories show that any marriage ceremony, where either of the parties belongs to a non-binary gender sphere or both, having been conducted

18 M.P. Jain, Indian Legal History (Lulu Press, Inc., 2014).

19 Amara Das Wilhelm, Tritiya-Prakriti: People of the Third Sex: Understanding Homosexuality, Transgender Identity, and Intersex Conditions Through Hinduism (Philadelphia: Xlibris Corporation, 2004).

20 Marvin Mahan Ellison \& Judith Plaskow, Heterosexism in Contemporary World Religion: Problem and Prospect 219 (Cleveland: Pilgrim, 2007).

21 Mark Philip Strasser et al., Defending Same-Sex Marriage: Volume 2 of Our Family Values Same-Sex Marriage and Religion (Westport, CT: Praeger, 2007).

22 Id.

23 Id.

24 Kanhu Charan Mishra, Studies in the Mahabharata (Bhubaneswar: Institute of Orissan Culture, 1989).

25 National Legal Services Authority v. Union of India and Ors., AIR 2014 SC 1863, at 14. 
in accordance with the customary rites and rituals of the location, will still retain its sanction or force by law. Thus, ancient Hindu customary laws of marriage also recognized non-binary marriages, thereby laying down a base for third gender marriages in India.

\section{Recognition of Third Gender in India}

The gender of an individual as opposed to the sex of that individual, scientifically speaking, is not merely restricted to the heteronormative idea of existence as male or female. The concept of gender not only is related to the physical characteristics of a person, but also is inclusive of the subtle psychological traits and a unique consideration of social interaction. ${ }^{26}$ Thus, gender is an inclusive umbrella term which includes an array of varied gender schemes between the two poles of heterosexual males and females. ${ }^{27}$ Since the ancient era, Vedic and Puranic literature have recognized the presence of three genders, viz. heterosexual male, heterosexual female and the tritiya prakriti or the third sex. ${ }^{28}$ The third gender category, commonly referred to as Hijras, in India, can be described as a natural combination of male and female features to such an extent that they cannot be categorized within the separate classification of two distinct binary genders, i.e. male and female. ${ }^{29} \mathrm{Hijras}$ are not men by virtue of anatomical appearance, and psychologically they are also not women, though they are like women, but have no female reproductive organs and they do not menstruate. ${ }^{30}$

In Hindu culture, Hijras were socially recognized and held a special status, for they ushered in blessings on auspicious occasions such as marriage or the birth of a child. With time, however, this elevated position of the Hijra community fell low, relegated to the dust, and incarceration. During the British Rule, third gender people were likened to a deadly disease that could infect society. In consequence, the Criminal Tribes Act was enacted in 1871, which granted powers to the government to apprehend third gender people for the mere apprehension of promiscuous activities. ${ }^{31}$ In this period the intersex Hijra community suffered immensely at the hands of law enforcement agencies that grossly abused their powers. Ultimately, the Act was repealed in August

\footnotetext{
26 Wilhelm 2004.

27 Fausto Sterling, Sexing the Body: Gender Politics and the Construct (New York: Basic Books, 2008).

28 Supra note 26; supra note 25, at 12.

29 Id.

30 Supra note 25 , at 11.

31 Criminal Tribes Act, Act XXVII of 1871.
} 
1949; however, the ill effects of the Act still continued. Hijras were deprived of the basic rights guaranteed under Part III of the Indian Constitution and were subjected to constant humiliation. ${ }^{32}$ Often, right up to today, society shuns and ridicules people from the third gender community. Heavy discrimination is directed against them merely because of their transsexual or intersex nature. ${ }^{33}$ As a result of this they join the secluded and ostracized Hijra community. But even there they live under the guru-chela system where, once again, they have to be subservient and submissive, this time to the gurus. ${ }^{34}$

Across the globe, seven countries have recognized the third gender community as a separate class of people fitting into neither male nor female categories. These include the states of Pakistan, ${ }^{35} \mathrm{Nepal}^{36}$ Australia, ${ }^{37}$ Bangladesh, Germany and New Zealand. Being influenced by these states as well as by the international obligations under different conventions and treaties, ${ }^{38}$ a major breakthrough came in 2015 when the Indian Supreme Court recognized the existence of third gender people. ${ }^{39}$ This was done to satisfy state obligations under international conventions and principles in respect of an individual's right against discrimination based on sex, right to equality and right to life and personal liberty. ${ }^{40}$ Furthermore, this ruling reinforced the idea that individuals have the option of choosing their own identity and that it is the state's duty to respect, protect and fulfil the human rights of these persons irrespective of

Supra note 25 , at $1,2,16 \& 44$.

General Comment No. 2, Implementation of Article 2 by States Parties, Committee Against Torture, CAT/C/GC/2, January 24, 2008; General Comment No. 20, Non-Discrimination in Economic, Social and Cultural Rights (Art. 2, Para. 2, of the International Covenant on Economic, Social and Cultural Rights), Committee on Economic, Social and Cultural Rights, E/C.12/GC/20, July 2, 2009.

Gayatri Reddy, With Respect to Sex: Negotiating Hijra Identity in South India (Chicago: University of Chicago Press, 2010).

Dr. Mohammad Aslam Khaki and Anr. v. Senior Superintendent of Police (Operation) Rawalpindi and Ors., Constitution Petition No. 43 of 2009 (decided on March 22, 2011).

Sunil Babu Pant and Ors. v. Nepal Government, Writ Petition No. 917 of 2007 (decided on December 21, 2007).

37 Norrie v. NSW Registrar of Births, Deaths and Marriages, (2013) NSWCA 145.

38 Universal Declaration of Human Rights, Art. 5; International Covenant on Civil and Political Rights, Art. 7; see also General Comment No. 2 (specifically deals with protection of individuals and groups made vulnerable by discrimination or marginalization); Universal Declaration of Human Rights, Art. 12 ("No one shall be subjected to arbitrary interference with his privacy, family, home or correspondence, nor to attacks upon his honour and reputation. Everyone has the right to the protection of the law against such interference or attacks."); International Covenant on Civil and Political Rights, Art. 12 ("1. No one shall be subjected to arbitrary or unlawful interference with his privacy, family, home or correspondence, nor to unlawful attacks on his honour and reputation. 2. Everyone has the right to the protection of the law against such interference or attacks.").

39 Supra note 25.

40 Id. 
their gender identity. ${ }^{41}$ The Court, in National Legal Services Authority, ${ }_{1}^{42}$ recognized third-sex people as a separate class apart from the straightjacket classification of gender as male and female, along with recognizing their civil right to vote, to receive education and to contest elections as well as to marry, to receive inheritance and to adopt children. ${ }^{43}$ Thus, gender recognition is the first step towards acknowledging the need and creating an enforcement mechanism for the array of human rights that every citizen including third-sex people are entitled to. Multiple problems faced by the third gender community with respect to marriage and other rights necessitate a variety of solutions and actions which need to be reflected in policies and the laws, and in the attitude of the government and the general public. ${ }^{44}$

\section{Legal Status of Marriage and Its Consequences under Hindu Law}

The codification of customary Hindu laws dates back to the mid $20^{\text {th }}$ century, the codification having been made for the purpose of creating a standardized pattern to solemnize Hindu marriage and its allied aspects in a more uniform manner. The parent legislation governing the performance of Hindu marriage lays down the essential concomitants of a valid marriage, as under S. 5 of the Hindu Marriage Act, 1955. The Act, aside from discussing the essentials of a valid marriage ${ }^{45}$ as mentioned, also enumerates on instances of voidable marriage ${ }_{1}^{46}$ void marriage, ${ }_{1}^{47}$ judicial separation ${ }^{48}$ restitution of conjugal rights ${ }_{, 9}^{49}$ divorce ${ }^{50}$ and all other such rights and duties that flow from a marriage between two individuals. For the context of establishing a valid marriage, a key factor is to determine the two personalities entwined in the marriage. However, one basic problem that individuals as well as interpreting authorities face while determining the validity of a marriage is when crucial terms establishing the capacity and ability of individuals to marry lack any concrete definition. The legislation currently in place fails to conclusively define key terms such as "bride" and "bridegroom" or the parties that constitute a valid

\footnotetext{
${ }^{41}$ National Legal Services Authority v. Union of India and Ors., at 23.

42 National Legal Services Authority v. Union of India and Ors., AIR 2014 SC 1863.

43 Id. at 45.6 .

44 Id.

45 S. 5, Hindu Marriage Act, 1955.

$46 \quad$ Id. S. 12.

47 Id. S. 11.

48 Id. S. 10.

49 Id. S. 9.

50 Id. S. 13.
} 
marriage..$^{51}$ Interestingly, however, the essential conditions as required of a valid Hindu marriage under S. 5 of the Act ${ }^{52}$ have by no means restricted the meaning as being that which is made only between a man and a woman. S. 2(1)(a) of the $\mathrm{Act}^{53}$ instead defines marriage as being applicable "to any person who is a Hindu by religion in any of its forms or developments." Although the legal definition of "marriage", as has been laid down through judicial interpretation, is a legal union of a man and woman as husband and wife, ${ }^{54}$ yet again these terms have not been defined under any law..$^{55}$

The primary principle of interpretation dictates that a constitutional or statutory provision should be construed literally, in accord with the legislative intent which is gathered from the words of the provision..$^{56}$ However, if the words used in the provision are imprecise or can reasonably bear multiple meanings, the rule of strict grammatical construction would cease to guide us through the real legislative intent. ${ }^{57}$ In such cases it would be incumbent on courts to go beyond the literal confines of the provision and to consider certain factors, namely, the legislative history, basic scheme and framework of the statute as a whole, the purpose of the legislation, the object sought to be achieved, and consequences that may flow from the adoption of one interpretation in preference to another possible interpretation..$^{58}$ Although, ordinarily, words should be neither added nor deleted from a statutory provision, there are some said exceptions to the rule. Where the alternative lies between either supplying by implication words which appear to have been accidentally omitted or adopting a strict construction which leads to absurdity or deprives certain existing words of all meaning, it may be permissible to supply words to the statute. ${ }^{59}$ In defining a marriage as being that which is performed only between a man and a woman, ${ }^{60}$ the courts could be said to have employed the aforementioned principle of interpretation, namely, supply of words in the event they have been accidentally omitted, although it could be argued that the legislative intent still remains ambiguous in light of the absence of any codified definition of

S. 5(iii), Hindu Marriage Act, 1955.

52 Id. S. 5 .

53 Id. S. 2(1)(a).

54 Reema Aggarwal v. Anupam and Ors., (2004) 3 SCC 199.

55 I. Jackuline Mary v. The Superintendent Of Police, W.P. No. 587 of 2014.

56 A.P. v. L.V.A. Dixitulu, (1979) 2 SCC 34.

57 Id.

58 Reserve Bank of India v. Peerless General Finance and Investment Co. Ltd. Ors., (1987) 1 SCC 424.

59 Justice G.P. Singh, Principles of Statutory Interpretation $71-76\left(9^{\text {th }}\right.$ ed., Nagpur: Wadhwa \& Co., 2004).

60 Supra note 55. 
marriage. ${ }^{61}$ The issue that has often been raised in regard to the terms "man" and "woman," as frequently found in any statute or legislation, is that these terms are never defined, neither in the body of the concerned statute nor in a pre-defining code or legislative act that would take precedence over all legislation so far as the interpretation and meaning of the terms in question would be concerned. ${ }^{62}$ Even though the words "male," "female," "bride," "bridegroom," "son" and "daughter" have been included as part of the basic text of a number of state enactments, such as the Hindu Marriage Act of 1955, the Special Marriage Act of 1954, the Pre-Conception and Pre-Natal Diagnostics Techniques Act of 1994, the Child Marriage Act of 2006 and the Hindu Succession Act, 1956, in addition to many others, the same legislation fails to define these common yet crucial terms which ultimately lay out an essential framework for the entire legislation. Further, the Hindu Succession Act, 1956, having even laid down a classification as to how the law would be applied differently in respect of a "male" Hindu and a "female" Hindu, ${ }^{63}$ nowhere defines the same nor lays down the elements differentiating the same. Even the General Clauses of the Interpretation Act of 1897 makes no mention of these definitions.

The Hindu Marriage Act, 1955 was legislated by lawmakers so as to primarily give effect to the customs and traditions presiding within the domain of Hindu law. ${ }^{64}$ A point of essential consideration is that historically Hindu law has been known to be inclusive of gender and sexual preferences that fall within a broad spectrum. ${ }^{65}$ So, what symptomatically progresses from this view is that the judiciary, through successive interpretations of the law, must accommodate within its definition of marriage the roles and qualifications to suit the real purpose of Hindu marriage, which is the spiritual union of two souls, and not procreation. ${ }^{66}$

One significant aspect of marriage pertains to the rights of inheritance and succession that are generated from the juridical solemnization of the marriage. The right of inheritance under Hindu law is based on the coparcenary model of succession and inheritance. ${ }^{67}$ This right of inheritance emanates from the concept of "Hindu joint family" which is understood as the principle of sapindaship. ${ }^{68} \mathrm{Hindu}$ joint

61 I. Jackuline Mary v. The Superintendent Of Police, W.P. No. 587 of 2014.

62 Id.

63 S. 6, Hindu Succession Act, Act No. 30 of 1956.

$6459^{\text {th }}$ Report on Hindu Marriage Act, 1955 and Special Marriage Act, 1954, Law Commission of India, March 1974.

65 Preeti Sharma, Historical Background and Legal Status of Third Gender in Indian Society, 2(12) IJRESS 64 (2012).

66 Reema Aggarwal v. Anupam and Ors., (2004) 3 SCC 199.

67 Maitrayee Mukhopadhyay, Legally Dispossessed: Gender, Identity, and the Process of Law (Calcutta: Stree, 1998).

68 Surjit Lal Chhabda v. Commissioner of Income Tax, AIR 1976 SC 109; Commissioner of Income Tax v. Ghansham Dass Mukim, (1979) 118 ITR 930 (P\&H). 
family can be considered as consisting of "a group of persons who are united by the tie of sapindaship arising by birth, marriage or adoption"69 that ultimately constitutes this larger body or organization. Furthermore, the Hindu Succession Act, 1956 even lays down a classification as to how the law would be applied differently in respect of a male and female coparcener, ${ }^{70}$ as also in case of a Hindu male or female dying intestate. ${ }^{11}$ In this setting, it is essential for an individual either to marry or to have a blood relationship so as to gain the right of inheritance and succession.

\section{The Case for an Inclusive Interpretation of Marriage}

The legal classification of gender clearly identifies two separate classes having their corresponding rights, that is, a man who can legally marry a woman and a woman who can legally marry a man. Despite this seemingly linear segregation, and its consequent assignment of rights, the existence of an unambiguous legal criterion that could actually enable the working of such segregation is absent. ${ }^{72}$ It is the fundamental right of an individual to marry and, therefore, it would be a question of grave prejudice if an entire group or class of society were precluded from the right to marry simply because they did not fit the definitions of "male" and "female," and any corollaries. When facing the challenge of deciding the legal validity of a marriage based on the sex or gender of the parties committed to the marriage, the court must take into consideration the legal sex of each and every individual. ${ }^{73}$ When it comes to determining the legal sex of an individual, different circumstances in the legal context call for different ways of dealing with the question, such ways not necessarily required to intersect. ${ }^{74}$

When the relevant terms of a legal statute have not been defined, the natural recourse is to consider their "ordinary meaning." ${ }^{175}$ However, when their "ordinary meaning" is resorted to, it must be seen that it does not obscure the context and purpose of the statutory legislation, in this specific instance the legislation concerning

69 See, e.g., Surjit, AIR 1976 ("The fundamental principle of the Hindu joint family is the sapindaship. Without that it is impossible to form a joint Hindu family. With it as long as a family is living together, it is almost impossible not to form a joint Hindu family. It is the family relation, the sapinda relation, which distinguishes the joint family, and is of its very essence."). Marriage, 30(6) Fordham Urb. L. J. (2002).

74 Supra note 72 .

75 W v. Registrar of Marriages, (2012) 1 HKC 88. 
marriage. ${ }^{76}$ Judicial declarations in foreign jurisdictions are seen to increasingly favour the interpretation of sex "for the purpose of marriage.".77 Judith Butler's performance theory assumes a particular significance in this regard, which is, in understanding the above-discussed relation of a person's "sex" to his or her marriage. According to Butler's theory, every person is primarily performing a "gender" role of his or her own construction or choice, based on social expectations, and particularly with respect to the specific relationship that he or she shares with another person, especially a relationship in an apparently sexual context. ${ }^{78}$ Now, based on the argumentative position of this theory, it may be put forward for assumption that, in a marriage existing between two partners, at least one of the partners, who is entering into a marital relationship with the other, adopts an identity which this partner knows as being distinct from his or her biological identity, meaning that, any one of the two partners in a marriage may choose to undertake either a feminine or a masculine gender role in contrast to the other partner. ${ }^{79}$

Butler's theory also determines the role of gender from the nature and manner of a person's living in the shared domestic household of his or her respective marriage partner, that is, with respect to the duties which each person has chosen to share in the marriage.$^{80}$ In this way, the conjugal performative aspect of Butler's theory erases the supposition of consummation as being an essential determinant of "marriage," thereby erasing also the identification of the "bride" and "bridegroom" with their concomitant traditional sexual roles and characteristics, and replacing it with a rather normative and mundane version of marriage, which on its face seems inclusive of people falling outside the non-ambiguous gender binary. ${ }^{81}$ Ultimately, legal constructs of sexual identity have the fundamental purpose of serving as a sorting mechanism rather than being held up as a mirror to our society. They are manifestations of the natural element of law, existing to simplify complex structures by segregating them into separate and identifiable classes. ${ }^{82}$

One must especially understand constructs of social implications such as marriage as being the "practical" and "forward looking" intention of the law to create legal relationships between different classes of people; and, in this context, legal

76 W v. Registrar of Marriages, at 50.

77 David B. Cruz, Getting Sex "Right": The Heteronormativity and Biologism in Trans and Intersex Marriage Litigation and Scholarship, 18 Duke Journal Gender Law \& Policy 203 (2010).

78 Shari L. Thurer, The End of Gender: A Psychological Autopsy 136 (New York: Routledge, 2005).

79 Vanita 2005

80 Chris Beasley et al., Homosexuality in Theory and Practice 35 (New York: Routledge, 2012).

81 Heather Brook, Conjugal Rites: Marriage and Marriage-like Relationships Before the Law (Dordrecht: Springer, 2007).

82 Laura Grenfell \& Anne Hewitt, Gender Regulation: Restrictive, Facilitative or Transformative Laws?, 34 Sydney Law Review 761 (2012). 
categories of sex and gender must be said to be calibrated in ways as to be made more accommodative of the variances exhibited by individuals in their respective gender spheres and also, thereby, to alleviate the psychological flagellations regularly imposed upon them by virtue of the natural existence of such variances. ${ }^{83}$ Furthermore, the discursive appreciation of sex having become an intrinsic as well as a fundamental principle of the entire legal system itself, it appears imperative to conclude that the whole gender/sex divide carries with it the import of having already been codified in a prominent legal domain, viz. the Constitution. ${ }^{84}$ Therefore, the stipulation of the meaning of gender-relevant terms in the Hindu Marriage Act and such allied laws would essentially give effect to the words of the Constitution itself, which has recognized the inclusion of third gender within the discretive "sex" of Article $14 .{ }^{85}$ Thus, a third gender individual may be validly permitted to assume the role of a "husband" or a "wife" as to the extent that the fulfilment of the essentials of a valid Hindu marriage is concerned.

\subsection{An Implication of Non-Recognition of Third Gender Rights under Personal Laws}

Non-recognition of third-sex marriage rights can have manifold implications. In a hijra gharana, the guru-chela relationship is of specific emphasis as there is a need for economic dependence along with a show of social control.$^{86}$ Thus, kinship flows in the closed Hijra community by means of affiliations and familial ties between gurus and chelas ${ }^{87}$ However, this kinship flows with a cost which the chelas have to pay by being subservient and tolerant to the whims and orders of their gurus, so as to meet the basic necessities of life which may merely amount to a square meal and a place to reside in. Hijras cannot live a life solely as they wish lest they may bear the misery of being ostracized and boycotted from their own community. ${ }^{88} \mathrm{In}$ lieu of the need for protection and to get certain limited inheritance rights in the property of the hijra gharana, these vulnerable Hijras still choose to remain within the four corners of their community despite the adversities they have to face even there. This brings us to the need for legalizing and recognizing marriage as well as the inheritance rights of third-sex people.

\footnotetext{
83 Dean Spade, Normal Life: Administrative Violence, Critical Trans Politics, and the Limits of Law 13 (New York: South End Press, 2011).

84 Critical Intersex (M. Holmes, ed., Farnham: Ashgate Publishing, 2012).

85 Supra note 25.

86 Serena Nanda, Neither Man nor Woman: The Hijras of India ( $2^{\text {nd }}$ ed., Belmont, CA:Wardsworth Publishing Co., 1999).

87 Id.

88 Reddy 2010, at 142.
} 
Recognizing the Hijra community's right to marry will lay the foundation for granting them the rights of succession, inheritance and adoption which are vital aspects of Hindu personal law. The judicial understanding of the term "Hindu joint family" and the "coparcenary model of inheritance" and sapindaship can be interpreted to include Hijras only when their initial right to marry is recognized.

\subsection{Recognizing Hijra Gharana's Right of Inheritance}

Now, the other less discussed aspect of the enforcement of rights of the third gender community under Hindu law as has been mentioned is the recognition of the inheritance rights of the hijra gharanas. Here, it first becomes pertinent to point out a striking note of comparison that exists between the Hijra community and a Hindu joint family. In a Hindu joint family, the person lower in the relationship status within the kinship needs the nurture and protection of the person who is more elevated in position, and will therefore show proper deference and loyalty to the superior. The same may be said of a hijra gharana where the emotional need for such a relationship is even more evident than among many Indian families today because of the fact that the Hijra community exists and sustains itself as both a kinship group as well as a work group. ${ }^{89}$ Since a hijra gharana has the same structural flow as that of a Hindu joint family, the legal plausibility of recognizing hijra gharanas along the lines of a Hindu joint family should receive immediate recognition, although the existing judicial principles if viewed in this regard offer little support. However, there has indeed been a shift in judicial understanding, over the years, in the interpretation of the term "Hindu undivided family" or "Hindu joint family". The Hindu joint family has been limited in its membership not only to a system that accommodates a coparcenary model of succession and inheritance but also to "a fringe of persons, males and females" ${ }^{\prime 90}$ who exist outside the limits of coparcenary. It remains to be seen whether, in the course of this evolution in judicial understanding of the term "Hindu joint family", the concept of sapindaship could also eventually be interpreted to cover the existing relationship between the members of hijra gharanas. One may especially consider the case of Aravanis of Tamil Nadu who are married to their deity of a local fame and significance by a priest. ${ }^{91}$ It is essential to determine whether the marriage of these Aravanis to this deity, who is otherwise a "juristic person" ${ }^{\prime \prime 2}$ in the eyes of the law, could be seen as

89 Reddy 2010, at 142.

90 Surjit Lal Chhabda v. Commissioner of Income Tax, AIR 1976 SC 109.

91 O. Somasundaram, Transgenderism: Facts and fictions, 51 Indian J Psychiatry 1, 73-75 (2009); see also Garry Ferrard \& Susan Andreatta, Cultural Anthropology: An Applied Perspective $\left(10^{\text {th }}\right.$ ed., Stamford, CT: Cengage Learning 2014).

92 See, e.g., Vidya Varuthi Thirtha v. Balusami Ayyar, (1922) 24 BOMLR 629 ("Under the Hindu law the image of a deity of the Hindu pantheon is, as has been aptly called, a 'juristic entity,' vested with the capacity of receiving gifts and holding property."); see also Shriomani Gurudwara Prabandhak 
constituting a valid marriage within the context of Hindu law, particularly in light of provision 3(a) of the Hindu Marriage Act, 1955, ${ }^{93}$ and whether such marriage, if found to be valid, could be said to form a valid sapinda relationship amongst the members of the community who are together given in consecration to such marriage. The implication of recognizing this marriage would be to recognize their inheritance right as well as to provide them with a secured life where they will live on an equal basis as other citizens.

\section{Conclusion}

The crucial yet intriguing questions with respect to third gender people's right of marriage and inheritance can be answered by a broader judicial interpretation, most importantly by bringing the much needed change in the law, in the aftermath of the third gender's recognition in the National Legal Services Authority ${ }^{94}$ judgment. As enumerated, the lack of clarity under Hindu personal law, in addition to the absence of legislation recognizing marriage and inheritance rights of third-sex people, subjects them to indefinite discrimination even though the Supreme Court has recognized their right of equality under Article 14 of the Indian Constitution. ${ }^{95}$ Indian laws relating to marriage, adoption, inheritance and other welfare legislation merely recognize the paradigm of binary genders of male and female which is based on a person's sex assigned at birth. ${ }^{96}$ However, this is a flawed approach especially in the contemporary scenario where third gender rights have been recognized globally and domestically. The doctrine of incorporation which stands at the base of India's international obligations mandates legislators to enact laws for implementing those recognized international principles so long as they do not contravene domestic provisions. $^{97}$

The Yogyakarta Principles address a broad range of human rights standards and their application to issues of sexual orientation and gender identity. ${ }^{98}$ These

Committee, Amritsar v. Shri Som Nath and Ors., AIR 2000 (3) SC 1421 (the term "juristic person" also connotes the "recognition of an entity to be in law a person which otherwise it is not. In other words, it is not an individual natural person but an artificially created person which is to be recognised to be in law as such.").

93 S. 3(a), Hindu Marriage Act, 1955.

94 National Legal Services Authority v. Union of India and Ors., AIR 2014 SC 1863.

95 Id. at $54,75,76 \& 77$.

96 Id. at 49.

97 Art. 51 \& 253, The Constitution of India, 1950 (Jan. 31, 2016), available at http://lawmin.nic.in/olwing/ coi/coi-english/Const.Pock\%202Pg.Rom8Fsss(2).pdf.

98 Routledge Handbook of International Human Rights Law (S. Sheeran \& Sir N. Rodley, eds., Abingdon: Routledge, 2013). 
principles even embody the duty on states to include interpretations and amendments to legislation so as to ensure equality and non-discrimination on the basis of gender identity or sexual orientation. ${ }^{99}$ Furthermore, these principles have been endorsed by the UN Special Rapporteur, ${ }^{100}$ regional human rights bodies, national courts, government commissions and commissions for human rights, and the Council of Europe as a human rights standard for protecting and fulfilling the human rights of all persons, regardless of their gender identification. ${ }^{101}$ Against this backdrop, it is the duty of Indian legislators to amend the current legislation governing Hindu personal law so as to bring it into consonance with India's international obligations as well as with its duty to protect the fundamental rights of the third gender community.

\section{References}

Ananthamurthy U.R. Samskara: A Rite for a Dead Man (Oxford: Oxford University Press, 2012).

Beasley C. et al. Homosexuality in Theory and Practice (New York: Routledge, 2012).

Bennett T. Cuts and Criminality: Body Alteration in Legal Discourse (Burlington, VT: Ashgate Publishing, 2015).

Brook H. Conjugal Rites: Marriage and Marriage-like Relationships Before the Law (Dordrecht: Springer, 2007).

Critical Intersex (M. Holmes, ed., Burlington, VT: Ashgate Publishing, 2009).

Cruz D.B. Getting Sex "Right": The Heteronormativity and Biologism in Trans and Intersex Marriage Litigation and Scholarship, 18 Duke Journal Gender Law \& Policy 203 (2010).

Druru N. Reincarnation: Exploring the Concept of Reincarnation in Religion, Philosophy and Traditional Cultures (New York: Barnes \& Nobles Books, 2002).

Ellison M.M. \& Plaskow J. Heterosexism in Contemporary World Religion: Problem and Prospect (Cleveland: Pilgrim, 2007).

Ferrard G. \& Andreatta S. Cultural Anthropology: An Applied Perspective $\left(10^{\text {th }}\right.$ ed., Stamford, CT: Cengage Learning, 2014).

Frankle R.E. Does A Marriage Really Need Sex?: A Critical Analysis of the Gender Restriction on Marriage, 30(6) Fordham Urb. L.J. (2002).

99 The Yogyakarta Principles: Principles on the Application of International Human Rights Law in Relation to Sexual Orientation and Gender Identity, International Commission of Jurists (2007), Prin. 2 (Jan. 31, 2016), available at http://www.yogyakartaprinciples.org/principles_en.htm.

100 Vernor Munoz, Report of the United Nations Special Rapporteur on the Right to Education, UN Doc. A/65/162, 23 (July 2010).

101 Douglas Sanders, International: The Role of Yogyakarta Principles, OutRight Action International (Jan. 31, 2016), available at https://www.outrightinternational.org/content/international-role-yogyakartaprinciples; National Legal Services Authority v. Union of India and Ors., AIR 2014 SC 1863, at 23. 
Grenfell L. \& Hewitt A. Gender Regulation: Restrictive, Facilitative or Transformative Laws?, 34 Sydney Law Review 761 (2012).

Jain M.P. Indian Legal History (Lulu Press, Inc., 2014).

Mishra K.C. Studies in the Mahabharata (Bhubaneswar: Institute of Orissan Culture, 1989).

Mishra R.C. Moksha and the Hindu Worldview, 25(1) Psychology \& Developing Societies (2013).

Mukhopadhyay M. Legally Dispossessed: Gender, Identity, and the Process of Law (Calcutta: Stree, 1998).

Mulla D.F. Sir. Mulla Hindu Law (12 $2^{\text {th }}$ ed., LexisNexis, 1960).

Nanda S. Neither Man nor Woman: The Hijras of India $\left(2^{\text {nd }}\right.$ ed., Belmont, CA: Wardsworth Publishing Co., 1999).

Pandey R. Hindu Samakaras: Socio-Religious Study of the Hindu Sacraments $\left(2^{\text {nd }}\right.$ ed., Delhi: Motilal Banarasidass Publishers, 1969).

Reddy G. With Respect to Sex: Negotiating Hijra Identity in South India (Chicago: University of Chicago Press, 2010).

Routledge Handbook of International Human Rights Law (S. Sheeran \& Sir N. Rodley, eds., Abingdon: Routledge, 2013).

Senghass D. The Clash within Civilisations: Coming to Terms with Cultural Conflicts (London: Routledge, 2005).

Sharma P. Historical Background and Legal Status of Third Gender in Indian Society, 2(12) IJRESS (2012).

Singh G.P. Justice. Principles of Statutory Interpretation $\left(9^{\text {th }}\right.$ ed., Nagpur: Wadhwa \& Co., 2004).

Somasundaram O. Transgenderism: Facts and fictions, 51(1) Indian J Psychiatry (2009).

Spade D. Normal Life: Administrative Violence, Critical Trans Politics, and the Limits of Law (New York: South End Press, 2011).

Sterling F. Sexing the Body: Gender Politics and the Construct (New York: Basic Books, 2008).

Strasser M.P. et al. Defending Same-Sex Marriage: Volume 2 of Our Family Values Same-Sex Marriage and Religion (Westport, CT: Praeger, 2007).

Thurer S.L. The End of Gender: A Psychological Autopsy (New York: Routledge, 2005).

Vanita R. Love's Rite: Same-Sex Marriage in India and the West (New York: Palgrave Macmillan, 2005; New Delhi: Penguin Books, 2005).

Wilhelm A.D. Tritiya-Prakriti: People of the Third Sex: Understanding Homosexuality, Transgender Identity, and Intersex Conditions Through Hinduism (Philadelphia: Xlibris Corporation, 2004). 


\section{Information about the authors}

Dipayan Chowdhury (Pune, India) - B.B.A. L.L.B. Student at Symbiosis Law School, Pune (Survey No. 227, Plot 11, Rohan Mithila, Opp. Pune Airport, New Airport Road, Viman Nagar, Pune, 411014, India; e-mail: d.chowdhury1993@gmail.com).

Atmaja Tripathy (Pune, India) - B.B.A. L.L.B. Student at Symbiosis Law School, Pune (Survey No. 227, Plot 11, Rohan Mithila, Opp. Pune Airport, New Airport Road, Viman Nagar, Pune, 411014, India; e-mail: atmajatripathy@gmail.com). 